\title{
PELAKSANAAN MANAJEMEN BERBASIS SEKOLAH (Studi Kasus Pada SMA Negeri 2 Katingan Hilir)
}

\author{
Oleh \\ Wilka* Bulkani**
}

\begin{abstract}
This study aims to: (1) To find out the implementation of school-based management (2) To find out the organization in the development of the curriculum used in the implementation of school-based management in Katingan Hilir 2 High School. This research was conducted in 2 (two) months, taking place at Katingan Hilir 2 High School, located on Tjilik Riwut km 2.5 road, Kasongan Lama Village. The method used in conducting this research is qualitative with the type of case study. The data collection techniques used are observation, interviews, and documentation. To test the objectivity and validity of the data used triangulation techniques, using reference materials, and holding member checks. Data analysis used is data reduction, data display and conclusion. The results showed that at Katingan Hilir 2 High School in Katingan District the implementation of school-based management had gone well. Because this can be done well because of the collaboration between the principal and the board of teachers and the school community.
\end{abstract}

Keywords: Management, School.

ABSTRAK
Penelitian ini bertujuan untuk:(1) Untuk mengetahui pelaksanaan manajemen berbasis sekolah (2) Untuk mengetahui organisasi dalam perkembangan kurikulum yang digunakan dalam pelaksanaan manajemen berbasis sekolah di SMA Negeri 2 Katingan Hilir. Penelitian ini dilaksanakan selama 2 (dua) bulan, bertempat di SMA Negeri 2 Katingan Hilir, yang berlokasi di jalan Tjilik Riwut km 2,5 Kelurahan Kasongan Lama. Metode yang digunakan dalam melakukan penelitian ini adalah kualitatif dengan jenis studi kasus. Adapun teknik pengumpulan data yang digunakan adalah observasi, wawancara, dan dokumentasi. Untuk menguji objektivitas dan keabsahan data digunakan teknik triangulasi, menggunakan bahan referensi, dan mengadakan member chek. Analisis data yang digunakan adalah reduksi data, display data dan pengambilan kesimpulan. Hasil penelitian menunjukan bahwa di SMA Negeri 2 Katingan Hilir Kabupaten Katingan pelaksanaan manajemen berbasis sekolah sudah berjalan dengan baik. Karena tersebut dapat terlaksana dengan baik karena adanya kerjasama antara kepala sekolah dengan dewan guru dan masyarakat sekolah.

Kata Kunci: Manajemen, Sekolah.

\section{PENDAHULUAN}

Pendidikan merupakan institusi penting bagi proses penyiapan dan peringatan kualitas sumber daya manusia yang benar-benar berkualitas. Pendidikan dapat diartikan sebagai suatu kegiatan yang sistematis dan terarah untuk membentuk kepribadian dan potensi peserta didik. Pada era globalisasi seperti saat ini, pendidikan memiliki peranan yang sangat penting dalam upaya untuk membawa suatu negara dalam kancah internasional.

Pembangunan pendidikan bukan hanya terfokus pada penyedian faktor input pendidikan tetapi juga harus lebih 
memperhatikan faktor proses pendidikan. Input yang baik tidak otomatis menjadi jaminan terjadinya peningkatan mutu. Bahkan selain input dan proses masih juga memperhatikan keragaman peserta didik, kondisi lingkungan dan peran serta masyarakat (termasuk alumnus).

Pendekatan baru yang dipertimbangkan lebih cocok untuk meningkatkan mutu pendidikan adalah pendekatan yang berbasis pada sekolah masing- masing. Pendekatan ini dikenal dengan "Manajemen Berbasis Sekolah" konsep ini menawarkan kerja sama yang erat antara sekolah (yayasan), masyarakat (Masyarakat setempat, masyarakat pengguna, masyarakat "peduli" dan alumnus) dan pemerintah (Dinas Pendidikan dan pemerintah setempat) dengan peran dan tanggung jawabnya masing-masing. Sekolah harus aktif dan dinamis dalam pengusahaan peningkatan mutu dengan peningkatan kemandirian sekaligus masih dalam kerangka acuan kebijakan pendidikan yayasan, nasional dan daerah.

Konsep peningkatan mutu pendidikan berbasis sekolah (MBS) muncul dalam kerangka pendekatan manajemen berbasis sekolah. Pada hakikatnya, MBS akan membawa kemajuan dalam dua area yang saling tergantung, yaitu kemajuan program pendidikan pelayanan kepada peserta didik-orang; dan kualitas lingkungan kerja untuk semua anggota organisasi. Manajemen Berbasis Sekolah diartikan sebagai model pengelolaan yang memberi otonomi (kewenangan dan tanggungjawab) lebih besar kepada sekolah, memberi fleksibilitas/keluwesankeluwesan kepada sekolah dan mendorong partisipasi secara langsung warga sekolah (guru, peserta didik, kepala sekolah, karyawan) dan masyarakat (orangtua peserta didik, tokoh masyarakat, ilmuwan, pengusaha dan sebagainya) untuk meningkatkan mutu sekolah berdasarkan kebijakan pendidikan nasional serta peraturan perundang-undangan yang berlaku. Dengan otonomi tersebut, sekolah diberikan kewenangan dan tanggungjawab untuk mengambil keputusan-keputusan sesuai dengan kebutuhan, sekolah serta masyarakat atau stakeholder yang ada.

Dalam menjelaskan mengenai pemimpin dan kepemimpinan, ada beberapa hal yang perlu diperhatikan, diantaranya ialah: (1) kekuasaan, dan kewenangan, yaitu kemampuan untuk bertindak bagi seorang pemimpin untuk menggerakan bawahannya agar mengikuti kehendaknya dalam mencapai tujuannya yang telah ditentukan, (2) kewibawaan, yaitu berbagai keunggulan tersebut, orang patuh dan bersedia melakukan kegiatan-kegiatan yang dikehendakinya, (3) kemampuan, yaitu keseluruhan daya baik berupa ketrampilan sosial maupun ketrampilan teknis yang melebihi orang lain.

Manajemen berbasis sekolah (MBS) merupakan sistem yang menuntut untuk dapat berdiri secara mandiri dan berdaya dalam menggali, mengalokasikan, menentu prioritas kerja, mengendali, serta mempertanggungjawabkan

pemberdayaan sumber daya yang dimiliki, baik kepada masyarakat maupun pemerintah. Untuk menciptakan sekolah lebih mandiri atau memberdayakan, 
dibutuhkan otonomi. Dalam MBS, dibutuhkan fleksibelitas yang lebih besar oleh kepala sekolah dalam mengelola sumber daya, dan mndorong partisipasi warga sekolah dan masyarakat untuk meningkatkan mutu pendidikan (Hasbullah, 2006:15).

Peran kepala sekolah dikaitkan dengan MBS adalah segala upaya yang dilakukan dan hasil yang dicapai oleh kepala sekolah dalam mengimplementasikan MBS disekolahnya untuk mewujudkan tujuan pendidikan secara efekif dan efisien. Sehubungan dengan itu, kepemimpinan kepala sekolah yang efektif dalam MBS Mampu memberdayakan guru-guru untuk melaksanakan proses pembelajaran dengan baik, lancar, dan produtif. Menyelesaikan tugas dan pekerjaan sesuai dengan waktu yang telah ditetapkan, menerapkan prinsip kepemimpinan yang sesuai dengan tingkat kedewasaan guru dan pegawai lain disekolah.

Pemberian otonomi kepada kepala sekolah, sebagai konsekuensi otonomi sekolah, mengharuskan kepala sekolah meningkatkan kemampuan intelegensi manajerialnya. Otonomi sekolah secara terang-terangan membutuhkan membutuhkan kepala sekolah yang terampil memanfaatkan kecerdasan intelegesia manajerialnya.

Intelegesi manajerial adalah kecerdasan memimpin dan terampil mengelola organisasi, dengan memanfaatkan berbagai sumber daya yang ada atau yang tersedia, sehingga dengan seluruh perangkat yang dimiliki organisasi menciptakan sinerji, diarah untuk menuju kepada pencapaian tujuan organisasi secara maksimal dan optimal.

Manajemen Berbasis Sekolah (MBS) yaitu model pengelolaan yang memberikan otonomi atau kemandirian kepada sekolah atau madrasah dan mendorong pengambilan keputusan partisipatif yang melibatkan secara langsung semua warga sekolah atau madrasah sesuai dengan standar pelayanan mutu yang ditetapkan oleh pemerintah pusat, Provinsi, Kabupaten dan Kota.Pengertian Manajemen Berbasis Sekolah (MBS) cms-formulasi Istilah manajemen berbasis sekolah merupakan terjemahan dari "school-based management". MBS merupakan paradigma baru pendidikan, yang memberikan otonomi luas pada tingkat sekolah ( pelibatan masyarakat ) dalam kerangka kebijakan pendidikan nasional.

Menurut Edmond yang dikutip Suryosubroto merupakan "alternatif baru dalam pengelolaan pendidikan yang lebih menekankan kepada kemandirian dan kreatifitas sekolah. Nurcholis mengatakan Manajemen berbasis sekolah (MBS) adalah bentuk alternatif sekolah sebagai hasil dari desentralisasi pendidikan".

Secara umum, manajemen peningkatan mutu berbasis sekolah (MPMBS) dapat diartikan sebagai model manajemen yang memberikan otonomi lebih besar kepada sekolah dan mendorong pengambilan keputusan partisipatif yang melibatkan secara langsung semua warga sekolah (guru, siswa, kepala sekolah, karyawan, orang tua siswa, dan masyarakat) untuk meningkatkan mutu sekolah berdasarkan kebijakan pendidikan nasional. Lebih lanjut istilah manajemen sekolah acapkali 
disandingkan dengan istilah administrasi sekolah. Berkaitan dengan itu, terdapat tiga pandangan berbeda; pertama, mengartikan administrasi lebih luas dari pada manajemen (manajemen merupakan inti dari administrasi); kedua, melihat manajemen lebih luas dari pada administrasi (administrasi merupakan inti dari manajemen); dan ketiga yang menganggap bahwa manajemen identik dengan administrasi. Dalam hal ini, istilah manajemen diartikan sama dengan istilah administrasi atau pengelolaan, yaitu segala usaha bersama untuk mendayagunakan sumber-sumber, baik personal maupun material, secara efektif dan efisien guna menunjang tercapainya tujuan pendidikan di sekolah secara optimal.

Manajemen Berbasis Sekolah merupakan wahana untuk mendidik sekolah, terutama sekolah yang selama ini memiliki tingkat ketergantungan tinggi terhadap pusat, menjadi sekolah yang mandiri, memiliki inisiatif, kreatifitas dan inovasi sendiri serta mampu untuk menggali dan mengembangkan potensipotensi lokal dalam rangka mencapai tujuan sekolah pada khususnya dan tujuan pendidikan nasional pada umumnya.
Menurut
B.
Suryosubroto (2004:196) menafsirkan bahwa "pada dasarnya manajemen berbasis sekolah merupakan suatu strategi pengelolaan penyelenggaraan pendidikan di sekolah yang menekankan pada pengerahan dan pendayagunaan sumber internal sekolah dan lingkungannya secara efektif dan efisien sehingga menghasilkan lulusan yang berkualitas atau bermutu".

Sehingga pada dasarnya konsep manajemen berbasis sekolah adalah strategi pemerintahan dalam menyelenggarakan pengelolaan pendidikan yang bergeser dari arah sentralistik menuju desentralistik yang berdampak pada keleluasaan pengelola sekolah terhadap pengelolaan sekolah yang melibatkan warga sekolah maupun masyarakat guna pencapaian tujuan pendidikan dan perundang-undangan yang berlaku dengan peningkatan mutu pendidikan.

Sekolah yang melaksanakan Manajemen Berbasis Sekolah adalah yang secara efektif dapat melaksanakan semua programnya, sehingga sekolah memiliki kualitas yang handal. Jadi sekolah yang bermutu seharusnya adalah sekolah efektif.

Manajemen Berbasis Sekolah atau School Based Management didefinisikan sebagai pemberian kewenangan kepada sekolah untuk bebas menata organisasi sekolah, manajemen persekolahan, pengelolaan kelas, optimalisasi kerjasama (kepala sekolah, orangtua dan guru) dan pemberian kesempatan yang kreatif dan inovarif kepada sekolah.

Manajemen sekolah secara langsung akan mempengaruhi dan menentukan efektif tidaknya kurikulum, berbagai peralatan belajar, waktu mengajar, dan proses pembelajaran. Dengan demikian, upaya peningkatan kualitas pendidikan harus dimulai dengan pembenahan manajemen sekolah, disamping peningkatan kualitas guru dan pengembangan sumber belajar.

Dalam manajemen berbasis sekolah terdiri dari tiga pilar yaitu:

1. Manajemen Sekolah

Manajemen sekolah adalah

proses pendayagunaan semua 
kompunen baik kompunen manusia maupun non manusia yang dimiliki sekolah dalam rangka mencapai tujuan secara efisien.

\section{PAKEM}

PAKEM merupakan inovasi pembelajaran yang menekakan keaktifan siswa pada setiap kegiatan pembelajaran. PAKEM singkatan dari pembelajaran aktif, kreatif, efektif, dan menyenangkan akan menciptakan kepercayaan diri dari siswa dengan tidak merasa tegang dan pembelajaran yang berlangsung tidak terasa membosankan.

3. Peran Serta Masyarakat

Peran serta masyarakat adalah ikut sertanya seluruh anggita masyarakat dalam memecahkan permasalahan-permasalahan

masyarakat tersebut. Dalam manjemen berbasis sekolahperan serta masyarkat berarti partisipasi seluruh anggita masyarakat dalam memecahkan permasalahanpermasalahan yang berkaitan dengan sekolah tersebut.

Mulyasa (2002 : 12) mengemukan bahwa Manajemen Berbasis Sekolah (MBS) merupakan suatu penawaran bagi sekolah untuk menyediakan pendidikan yang lebih baik dan lebih memadai bagi para peserta didik.

\section{METODE PENELITIAN}

Pendekatan yang digunakan peneliti ini adalah pendekatan kualitatif dengan jenis studi kasus. Dengan kata lain penelitian ini menggunakan pendekatan naturalistik yang salah satunya dengan menggunakan pendapat informan di SMA Negeri 2 Katingan Hilir.

Denzim dan Lincoln (dalam Moleong, 2009:5) menyatakan bahwa penelitian kualitatif adalah penelitian yang menggunakan latar alamiah, dengan maksud menafsirkan fenomena yang terjadi dan dilakukan dengan jalan melibatkan metode yang ada.

Menurut Sugiyono menyebutkan: Metode penelitian kualitatif adalah metode penelitian yang berlandaskan pada filsafat postpositivisme, digunakan untuk meneliti pada kondisi obyek yang alamiah, (sebagai lawanya adalah eksperimen) dimana peneliti adalah sebagai intrumen kunci, snowball, teknik pengumpulan dengan trianggulasi (gabungan), analisis data bersifat induktif/kualitatif, dan hasil penelitian kualitatif lebih menekankan makna daripada generalisasi.

Sedangkan menurut Bogdan dan Taylor (Moleong, 2012:4) penelitian kualitatif adalah prosedur penelitian yang menghasilkan data deskriptif berupa katakata tertulis dan lisan dari orang-orang dan perilaku yang dapat diamati.

Pada penelitian jenis ini, peneliti mengumpulkan data mengganggu informan. Untuk memperoleh situasi yang atau wajar, peneliti tidak menonjolkan diri pada saat obsesvasi. Bila ia telah sering berada di situasi tersebut, maka ia tidak di anggap lagi sebagai orang luar yang menganggu situasi kewajaran. Peneliti pendekatan kualitatif dengan jenis studi kusus pada dasarnya adalah mencoba menggali tentang pelaksanaan manajemen berbasis SMAN-2 Katingan Hilir. 
Dalam penelitian ini, peneliti bermaksud mengkaji secara mendalam mengenai pelaksanaan pembelajaran di SMAN-2 Katingan Hilir. Penelitian kualitatif hakekatnya ialah mengamati orang dalam lingkungan hidupnya. Berinteraksi dengan mereka, berusaha memahamin bahasa dan tafsiran mereka, tentang dunia/lingkungan sekitarnya. Seorang peneliti yang mengadakan penelitian biasanya berorientasi pada orientasi teoretis.

Peneliti berusaha mengarahkan diri semaksimal mungkin dalam melakukan penelitian ini, dengan melakukan upayaupaya sebagai berikut:

1. Mengambil data dalam suasana yang wajar tanpa manipulasi situasi.

2. Data yang di ambil sesuai fokus penelitian dan menggali informasi sampai ketitik jenuh.

3. Laporan disusun secara deskritif dengan mengutamakan hasil.

4. Analisa data yang dilakukan secara terus menerus untuk mencari makna yang bersifat atau yang sesuai dengan pendapat subjek yang diteliti.

Subjek yang diteliti dalam penelitian kualitatif memiliki kedudukan yang sama peneliti. Subjek yang diteliti dipandang memiliki kedudukan sama dengan peneliti, jadi tidak sebagai objek atau yang lebih rendah kedudukannya akan tetap sebagai manusia setaraf. Peneliti tidak menganggap dirinya lebih tinggi atau lebih tau. Ia datang untukbelajar, untuk menambah pengetahuan dan pemahamannya. Berdasarkan hal tersebut peneliti menyatakan bahwa objek dalam penelitian ini sekaligus bertindak sebagai subjek penelitian. Oleh karena itu, dalam penelitian ini SMAN-2 Katingan Hilir merupakan objek penelitian.

\section{HASIL PEMBAHASAN}

Sumber daya manusia memberdayakan staf dan menempatkan personel yang dapat melayani keperluan semua peserta didik. Memilih staf yang memiliki wawasan manajemen berbasis sekolah. Sumber daya dan administrasi Mengidentifikasi sumber daya yang diperlukan dan mengalokasikan sumber daya tersebut sesuai dengan kebutuhan. Mengelola dana sekolah. Dan menyediakan dukungan administrasi.

1. Organisasi sekolah organisasi sekolah Menyediakan menajemen organisasi kepemimpinan transformasional dalam mencapai tujuan sekolah. Menyusun rencana sekolah dan merumuskan kebijakan untuk sekolah mandiri, dan mengelola kegiatan operasional sekolah, proses belajar mengajar meningkatkan kualitas belajar peserta didik, mengembangkan kurikulum yang cocok terhadap kebutuhan peserta didik dan masyarakat sekolah serta menyelenggarakan pengajaran yang efektif. Pada dasarnya manajemen adalah suatu proses pemanfaatan semua sumber daya organisasi untuk mencapai tujuan dengan melaksanakan funsi-fungsi perencanaan, pengambilan keputusan, pengorganisasian dari semua kegiatan dan sumber-sumber yang dimiliki. Pelaksanaan manajemen berbasis Sekolah pada SMA Negeri 2 Katingan Hilir 
mudah berkembang dengan baik. Karena adanya kerja sama antar Kepala Sekolah dengan dewan guru, dan masyarakat sekolah.

2. Pelaksanaan manajemen berbasis sekolah di SMA Negeri 2 Katingan Hilir. Pelaksanaan manajemen berbasis sekolah terdiri dari beberapa pilar salah satunya PAKEM merupakan inovasi pembelajaran yang menekakan keaktifan siswa pada setiap kegiatan pembelajaran. PAKEM singkatan dari pembelajaran aktif, kreatif, efektif, dan menyenangkan akan menciptakan kepercayaan diri dari siswa dengan tidak merasa tegang dan pembelajaran yang berlangsung tidak terasa membosankan. Menurut Wina Sanjaya (2006:273) menyatakan bahwa proses pembelajaran merupakan suatu sistem. Dengan demikian, pencapaian standar proses untuk meningkatkan kualitas pendidikan dapat dimulai dari menganalisis setiap kompunen yang dapat membentuk dan memengaruhi proses pembelajaran. Begitu banyak kompunen yang dapat mempengaruhi proses kualitas pendidikan. Namun demikian, tidak munkin upaya meningkatkan kualitas dilakukan dengan memperbaiki setiap kompunen secara serempak. Hal ini memang wajar, sebab guru merupakan ujung tombak yang berhubungan langsung dengan peserta didik sebagai subjek dan objek belajar. Berdasarkan hasil wawancara dengan peserta didik di atas pelaksanaan pebelajaran di kelas masih belum berjalan dengan efektif, katrena guru yang mengajar masih dalam proses belajar. Bagaimanpun bagus dan idealnya kurikulum pendidikan, bagaimanapun kelengkapan sarana dan prasarana pendidikan tanpa diimbangi dengan kemampuan guru dalam mengimplementasikannya, maka semuanya akan kurang bermakna. Oleh sebab itu, untuk mencapai standar proses pendidikan, sebaiknya dengan menganalisis komponen guru.

3. Sumber daya manusia memberdayakan staf dan menempatkan personel yang dapat melayani keperluan semua peserta didik. Memilih staf yang memiliki wawasan manajemen berbasis sekolah. Manajemen berbasis sekolah adalah bentuk alternatif sekolah sebagai hasil dari desentralisasi dalam bidang pendidikan. Sebagai wujud dari reformasi pendidikan, MBS pada prinsipnya bertumpu pada sekolah dan masyarakat serta jauh dari birokrasi yang sentralistik. MBS berpotensi untuk meningkatkan partisipasi masyarakat, pemerataan, efesiensi, serta manajemen bertumpu ditingkat sekolah. Model ini dimaksud untuk menjamin semakin rendahnya kontrol pemerintah pusat, dan di pihak lain semakin meningkatnya otonom sekolah untuk menentukan sendiri apa yang perlu diajarkan dan mengelola sumber daya yang ada untuk berinovasi. Berdasarkan 
uraian dan hasil wawancara di atas dapat disimpulkan HT bahwa penugasan guru untuk melayani semua keperluan peserta didik ini tidak masing-masing ketentuan gurunya. Seperti contohnya wakasek kesiswaan, tentu mengawasi tentang kesiswaan.

Ditinjau dari pengelolaan pendidikan di sekolah Kepala sekolah akan selalu menghadapi masalah pengelolaan biaya pendidikan yang kurang efisien, karena mereka terbiasa hanya menjalankan perintah pejabat diatasnya, dan bukan bekerja karena inisiatif, visi dan misi sekolah sendiri. Dengan demikian para kepala sekolah menjadi kaku dalam mengelola dana masyarakat, karena takut membuat kesalahan jika tidak mengikuti petunjuk pelaksanaan dan petunjuk teknis yang berlaku.

Sebagai pemimpin, seorang kepala sekolah yaitu tingkat dimana seorang pemimpin mendefinisikan dan merancang peran dirinya serta peran-peran bawahannya kearah pencapaian tujuan kelompok. Perilaku kepemimipinan yang lain adalah kategori keputusan kepemimpinan menerapkan konsiderasi (partisipasi) pada bawahannya atau anggota kelompoknya sesuai dengan jenis keputusan yang akan diambil disesuaikan dengan keinginan bawahan atau anggotanya.

Motivasi sekolah adalah sebuah tempat menyemai calon-calon ilmuan maupun tenaga terampil terdidik, yang siap membangun masyarakat dan bangsanya. Sadar dengan tugasnya, maka tugas sekolah menyediakan proses pembelajaran yang berkualitas, dengan harapan dapat menghasilkan lulusan yang cerdas, terampil, berakhlaq, serta mampu memasuki pasar kerja nasional maupun global.

Sebagai pendidik, seorang guru memusatkan perhatian kepada kepribadian peserta didik khususnya berkenaan dengan kebangkitan belajar. Guru yang mengajar peserta didik adalah seorang pribadi yang tumbuh menjadi penyandang profesi guru bidang tertentu.

Proses mengajar sampai puncaknya pada hasil belajar peserta didik. Proses belajar berhenti untuk sementara, dan terjadilah penilaian yang dimaksud adalah penentuan sampai sesuatu dipandang berharga, bermutu dan bernilai. Sesuai dengan teknis analisis data yang diperoleh yaitu kualitatif deskriftif (pemeparan) dengan menganalisis data yang telah peneliti kumpulkan dari hasil observasi, wawancara, dan dokumentasi selama peneliti mengadakan penelitian di SMA Negeri 2 Katingan Hilir.

\section{KESIMPULAN}

Berdasarkan temuan-temuan dan hasil pembahasan maka dapat disimpulkan bahwa Pelaksanaan Manajemen Berbasis Sekolah SMA Negeri 2 Katingan Hilir sudah mengarah ke hal yang baik sebagai berikut:

1. Kepala sekolah mampu kerjasama dengan dewan guru.

2. Kegiatan belajar mengajar berjalan dengan efektif dan lancar.

3. Dibutuhkan komitmen bersama mewujudkan visi dan misi disekolah.

4. Dengan kemauan dan kesanggupan kerja keras, serta motivasi yang 
tinggi, didukung dengan komitmen yang tinggi dari semua elemen sekolah, maka akan diperoleh hasil yang dapat memuaskan sesuai dengan harapan masyarakat.

Hal tersebut ditandai dengan proses pelaksanaan dalam mengembangkan sekolah kepala sekolah dan dewan guru sudah berjalan dengan baik dan optimal dengan adanya perubahan dalam kurikulum yang digunakan, sehingga pelaksanaan pendidikan ada peningkatan disekolah tersebut. Selain itu, kepala sekolah dan dewan guru serta masyarakat sekolah sudah bekerja sama dalam melaksanakan pengembangan sekolah agar sekolah maju, berkembang dan bermutu.

\section{DAFTAR PUSTAKA}

Hasbullah. 2006. Otonomi Pendidikan, Kebijakan Otonomi Daerah \&
Implikasinya terhadap Penyelenggaraan Pendidikan. Jakarta: PT RajaGrafindo Persada Lexy J, Moleong. (2012). Metodologi Penelitian Kualitatif. Bandung: Remaja Rosdakarya

Lexy J. Moleong, 2009. Metodologi Penelitian Kualitatif, Bandung : Remaja Rosdakarya

Mulyasa. 2012. Praktik Penelitian Tindakan Kelas. Bandung : PT Remaja Rosda Karya.

Sugiyono, (2010). Metode Penelitian Pendidikan. Bandung : Alfabeta

Suryosubroto B. 2009. Proses Belajar Mengajar di Sekolah. Jakarta : PT Rineka Cipta.

Wina Sanjaya. 2006. Strategi Pembelajaran Beriroentasi Standar proses Pendidikan. Jakarta: Kencana Prenada Media. 